\title{
The Effects of Short-Time Solution Treatment and Short-Time Aging on Mechanical Properties of Ti-6Al-4V for Orthopaedic Applications
}

\author{
Abdul Ajiz, Gunawarman, Jon Affi \\ Department of Mechanical Engineering, Andalas University, Limau Manis-Pauh, Padang, 25137, Indonesia \\ E-mail: papareza81@gmail.com,gunawarman@unand.ac.id,jonaffi@unand.ac.id
}

\begin{abstract}
The Ti-6Al-4V alloy is currently utilized as structural materials in artificial hip and knee joints, bone plates and screws, and artificial dental roots. It is mainly used in implants that replace hard tissue because has a high strength, good corrosion resistance, high biocompatibility compared to other conventional metallic biomaterials such as stainless steel and Co-Cr-Mo alloys. The Ti-6Al-4V alloy with low Young's modulus equivalent to that of the cortical bone is a simultaneously required in order to inhibit bone absorption. By short-time solution treatment and subsquent short-time aging, the mechanical properties of $\mathrm{Ti}-6 \mathrm{Al}-4 \mathrm{~V}$ alloy can be improved while maintaining a low Young's modulus. The result showed optimum heat treatments were solution treatment at 930 oC $(1203 \mathrm{~K})$ for $60 \mathrm{~s}$ and subsquent aging at $530 \mathrm{oC}(803 \mathrm{~K})$ for $40 \mathrm{~s}$; the yield strength and tensile strength improved without reduction in ductility. Their maximum improvement rates of reached $21,6 \%$ and $21,1 \%$, respectively and the Young's modulus reduced with maximum rates of reached $12 \%$.
\end{abstract}

Keywords-Ti-6Al-4V, short-time solution treatment, short-time aging, mechanical properties.

\section{INTRODUCTION}

The development of economy and technology, the number of aged people demanding failed tissue replacement is rapidly increasing. Elderly people have a higher risk of hard tissue failure. It is estimated that $70 \%-80 \%$ of biomedical implants are made of metallic materials. Metallic implants are remarkably important for the reconstruction of failed hard tissue and the market growth rate remains at around $20 \%$ and $25 \%$ [1]. The population ratio of the aged people of representative countries is rapidly growing. With the increasing cases of fracture, the need for bone replacement (orthopedic implants) increased. More than 7 million implant system has been placed in the human body, more than 1,000,000 implantansi spinal rod has been carried out between 1980-2000. Not only replacement surgery is growing, but also implant revision surgery on the hip and knee. It is estimated that the number of hip revision surgery increased by up to $137 \%$ and knee revision surgery increased by $607 \%$ between the years 2005 to 2030 [2].

Metallic biomaterials have essentially three fields of use; these are the artificial hip joints,screw, plates and nails for internal fixation of fractures, and dental implants. Any of these devices must support high mechanical load and resistance of material against breakage is essential. High mechanical properties are needed for structural efficiency of surgical and dental implants [2],[3]. The use of titanium alloys is due to their excellent corrosion resistance. Also, that is because of their tensile strength, a high strength to weight ratio and low elastic modulus. Titanium continues to be widely used in biomedical applications. Ti-6Al-4V alloy is the most frequently used these days [2],[3].

Research lately has been focusing on reducing Young's modulus and tensile properties of Ti-6Al-4V alloy. Since mechanical and tribological characteristics of Ti-6Al-4V alloy are most compatible with bone characteristics, in comparison with other biometallic materials such as stainless steels and Co-Cr based alloys [5]. The strength as well as Young's modulus of titanium alloys is a very important factor for their long-term use in implants for biomedical applications. However, it has been a problem that, there is a contradiction between the elastic modulus and other mechanical properties. When the elastic modulus is reduced, the strength of the titanium alloy is also decreased. Conversely, when the strength is enhanced, the elastic modulus is also increased.

The yield strength and tensile strength of Ti-6Al-4V is significantly improved over the years by conducting aging treatment after solution treatment or thermo-mechanical processing including severe cold working followed by aging treatment. This series of heat treatment is improved the mechanical biocompatiblity of alloy. With regard to the mechanical biocompatibility, Young's modulus is the major 
factor, and its value for the alloy should be equivalent to that of the cortical bone in order the stress transfer between an implant device and a bone is not homogeneous when Young's moduli of the implant device and the bone are different (Stress shielding phenomenon). Stress shielding causes loosening of the implants such as artificial joints or bone re-fracture after extraction of the implants. [3]-[5].

In the previous study, Morita et. al. [7] investigated the effect of short-time duplex heat treatment on the mechanical properties of the Ti-6Al-4V alloy, consisting of solutiontreated at $1203 \mathrm{~K}$ for $60 \mathrm{~s}$ in air and water-quenched, and aged at $753-953 \mathrm{~K}$ for $40 \mathrm{~s}-16.2 \mathrm{ks}$. As a result, the STQ treatment consisting of solution treatment at $1203 \mathrm{~K}$ for $60 \mathrm{~s}$ and water-quenching, the tensile strength of $\mathrm{Ti}-6 \mathrm{Al}-4 \mathrm{~V}$ alloy was improved with an increase of ductility and subsequent aging at 753-953 $\mathrm{K}$ for $40 \mathrm{~s}$ further improved both the yield strength and tensile strength of the STQtreated material. The most appropriate heat treatment conducted in this study was the STA treatment consisting of STQ treatment at $1203 \mathrm{~K}$ for $60 \mathrm{~s}$ and aging at $853 \mathrm{~K}$ for 40 s. With this heat treatment, the yield strength and tensile strength were each increased by about $25 \%$ and the reduction of area was slightly increased, by about $9 \%$.

In the other study, Morita et al. [9] investigated the effect of duplex heat treatment on microstructure and fatique strength of Ti-6Al-4V, consisting of STQ treatment at 1203 $\mathrm{K}$ for $60 \mathrm{~s}$ and short-time aging at at 753, 803, 853 and 903 $\mathrm{K}$ for $40 \mathrm{~s}$ and air-cooled. As a result, the short-time duplex heat treatment greatly increased the tensile strength and fatigue strength of $\mathrm{Ti}-6 \mathrm{Al} 4 \mathrm{~V}$ alloy without reduction in ductility. The most appropriate heat treatment was composed of STQ treatment at $1203 \mathrm{~K}$ for $60 \mathrm{~s}$ and short-time aging at $803 \mathrm{~K}$ for $40 \mathrm{~s}$. Through this duplex heat treatment, the improvement rates of the tensile strength and fatigue strength reached $29 \%$ and $22 \%$, respectively [9].

From the above back ground, this study comprehensively investigated the effects of the short-time solution treatment and subsquent short-time aging on mechanical properties of Ti-6Al-4V alloy at the lower aging temperatur then previous study. For the heat-treated materials, we carried out tensile tests.

\section{MATERIAL AND METHODS}

The chemical composition of Ti-6Al-4V alloy used in this study shown in Table I (SEM Hitachi S-3400N Observation).

TABLE I

CHEMICAL COMPOSITIONS OF TI-6AL-4V ALLOY IN THIS STUDy (\% MASS)

\begin{tabular}{|c|c|c|c|}
\hline $\mathrm{Al}$ & $\mathrm{V}$ & $\mathrm{Ti}$ & Others \\
\hline 5,76 & 3,91 & 88,58 & 1,75 \\
\hline
\end{tabular}

The tensile tests were conducted on transverse oriented test specimens. The specimen for tensile properties test prepared conformance to ASTM E-8, the tension testing methods for metallic material at room temperature, (smallsizes specimen proportional to standard) [13]. The material was supplied as round bars (diameter: $6 \mathrm{~mm}$ ) and machined to the twenty two specimen shapes shown in Figure 1: (nontreated $=2$ pieces, for solution treatment $=2$ pieces, and for the series of solution annealing treatment and subsquent aging $=18$ pieces). Specimens machined in CNC EMCO TU 2A type lathe machine.

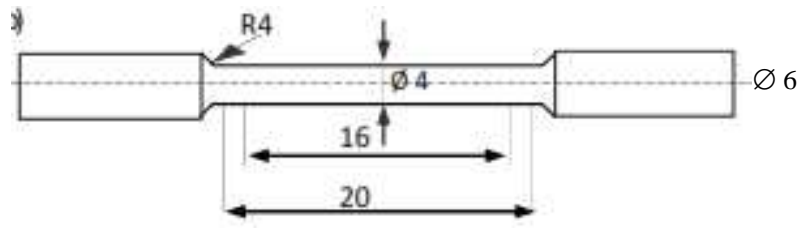

Fig. 1 Geometric and size for micro specimen tensile test (mm)

\section{A. Short-time Solutions treatment and Subsquent Short-time Aging}

For the short-time solution treatment, the specimens were kept at $1203 \mathrm{~K}$ for $60 \mathrm{~s}$ (heating time choosed $480 \mathrm{~s}$ ) and quenched (quenching time choosed $>20$ s) [18]. These specimens were subsequent aged at temperatur 490, 510 and $530{ }^{\circ} \mathrm{C}(763,783$ and $803 \mathrm{~K})$, for $40 \mathrm{~s}$ (heating time : $720 \mathrm{~s}$ ) and air cooled (Fig. 2) [11],[12]. The specimen heat treated in electric vacuum furnace (NEY CERAMFIRE $\mathrm{S}, \mathrm{T}_{\max }=$ $\left.1200{ }^{\circ} \mathrm{C} / 2292{ }^{\circ} \mathrm{F}\right)$.

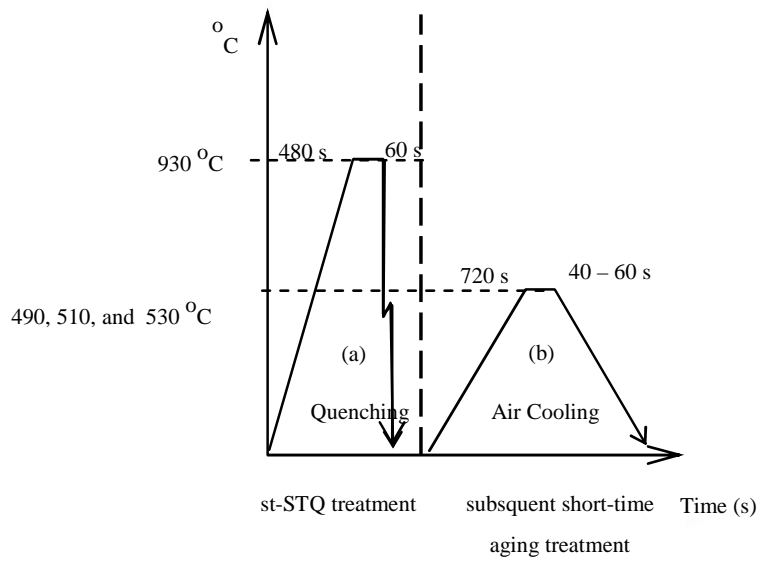

Fig. 2. Conditions of (a) short-time solution treatment and (b) subsquent short-time aging

\section{B. Tensile Test}

Tensile properties of nun-treated and solution annealing treated and subsquent aging treated of Ti-6Al-4V alloy obtained from tensile test. Uniaxial tensile tests were performed on a fully-automated, closed-loop servo-hydraulic mechanical test machine [GALDABINI] using a $100 \mathrm{KN}$ load cell. The tests were conducted in the room temperature, laboratory air (relative humidity of $55 \%$ ) environment.

The test specimens were deformed at a constant strain rate of $0 \cdot 0001 / \mathrm{sec}$. An axial 16.0-mm gage length hold-on specimen holder of machine. The stress and strain measurements, parallel to the load line, and the resultant mechanical properties of stiffness, strength (yield strength and ultimate tensile strength), and ductility (quantified as strain-to-failure) was provided as a computer output by the control unit of the test machine. 


\section{RESULTS AND DISCUSSION}

\section{A. Short-time Solution Treatment And Subsquent Short-time} Aging for $40 \mathrm{~s}$

Tensile properties of the Ti-6Al-4V alloy obtain from tensile test on the longitudinal oriented specimens. Tensile test conducted to alloys were heat treated by shor-time solution treatment and subsquent aging at various temperature in vacuum furnace, they are 490, 510 dan 530 ${ }^{\circ} \mathrm{C}$ for $40 \mathrm{~s}$. It was used two heat treated and fully polished specimens for each temperature and the results of test shown in the Table II.

TABLE III

Change In Mechanical Properties Of Ti-6al-4V With Short-Time SOLUTION TREATMENT AND SUBSEQUENT SHORT-TIME AGING For $40 \mathrm{~s}$

\begin{tabular}{|c|l|c|c|c|c|c|r|r|}
\hline No. & $\begin{array}{l}\text { Type } \\
\text { Treat- } \\
\text { ment }\end{array}$ & $\sigma_{\mathrm{ys}}$ & $\sigma_{\mathrm{ts}}$ & $\varepsilon$ & $\phi$ & $\frac{\sigma_{y s}}{\sigma_{t z}}$ & $\mathrm{E}$ & Duc. \\
\hline 1 & Non & 1005 & 1086 & 0,145 & 0,34 & 0,93 & 100 & 0,14 \\
\hline 2 & STQ & 1087 & 1187 & 0,153 & 0,47 & 0,92 & 133 & 0,15 \\
\hline 3 & $490^{\circ} \mathrm{C}$ & 1160 & 1286 & 0,122 & 0,36 & 0,90 & 96 & 0,15 \\
\hline 4 & $510^{\circ} \mathrm{C}$ & 1045 & 1129 & 0,122 & 0,36 & 0,93 & 102 & 0,15 \\
\hline 5 & $530^{\circ} \mathrm{C}$ & 1282 & 1377 & 0,122 & 0,37 & 0,93 & 87 & 0,15 \\
\hline
\end{tabular}

The results of tensile test which summarized on Table 4.1 shown the changing in tensile properties of heat treated alloy by short-time solution treatment subsequent short-time aging treatment for $40 \mathrm{~s}$. Representative changing in tensile properties alloy both untreated and heat treated shown in Figure 2.

The yield and ultimate tensile strength values of alloys after short-time solution treatment conform to the values of untreated one. The values of the yield ultimate tensile strength obtained in this study is 7,5\% and 8,5\% higher than the values on untreated alloy respectly. The Yield strength increases from 1005 to $1087 \mathrm{MPa}$, while the ultimate tensile strength increases from 1086 to $1187 \mathrm{MPa}$.

Also, the reduction of area determined in this study is noticeably higher, by as much as $28 \%$, than the value obtained in the untreated alloy. It was increased from 34 to 47\%. (as shown on Figure 3.1)

By subsquent short-time aging treatment, both yield and tensile strength increased higher than those only Solution treatment. The highest yield and ultimate tensile strength value were in the alloy that heat treated by subsquent shorttime aging at temperature, $\mathrm{T}=530{ }^{\circ} \mathrm{C}(803 \mathrm{~K})$. They are 21,6 and $21,1 \%$, respectively. The yield strength increased from 1005 to $1282 \mathrm{MPa}$ and ultimate tensile strength increased from 1086 menjadi $1377 \mathrm{MPa}$. Whereas, the lowest once on alloy that heat treated by subsquent Aging at temperature $\mathrm{T}=510{ }^{\circ} \mathrm{C}(783 \mathrm{~K})$. The yield and ultimate tensile strength increased only from 1005 to $1045 \mathrm{MPa}$ and $1086 \mathrm{MPa}$ to $1129 \mathrm{MPa}$, respectively.

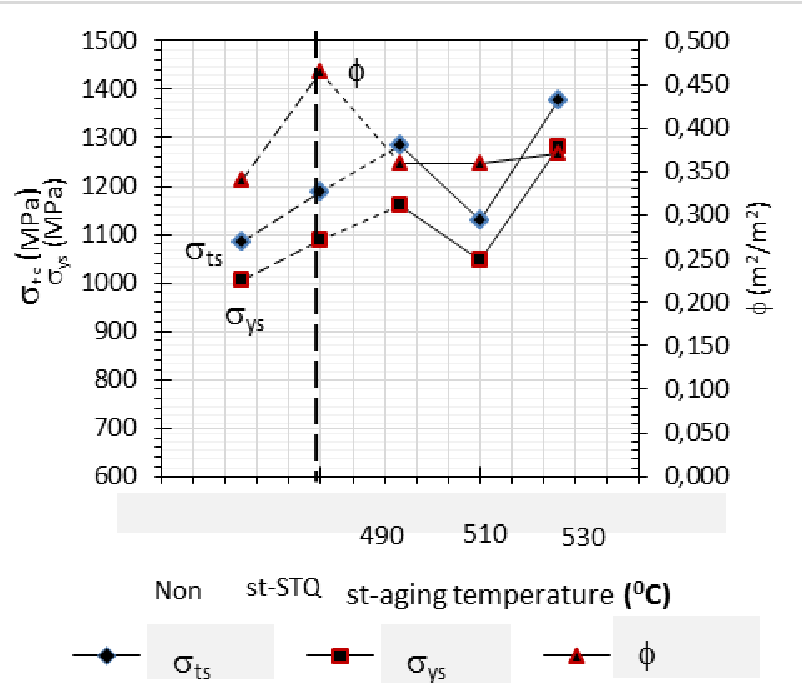

Fig. 3 Change in mechanical properties of Ti-6Al-4V with short-time solution treatment and subsequent short-time aging for $40 \mathrm{~s}$.

Figure 3 shows the heat treated alloy by subsquent shorttime aging, elongation determined in this study is noticeably higher, by as much as $6,6 \%$, than the value obtained in the untreated alloy. It was increased from 14 to $15 \%$.

Also, ductility of subsquent short-time aging alloy determined in this study is noticeably higher, by as much as $6,6 \%$, than the value obtained in the untreated alloy. It was increased from 14 to $15 \%$. The yield ratio of Solution treatment alloy decreased from 0,93 to 0,92 at temperature $510{ }^{\circ} \mathrm{C}(783 \mathrm{~K})$.

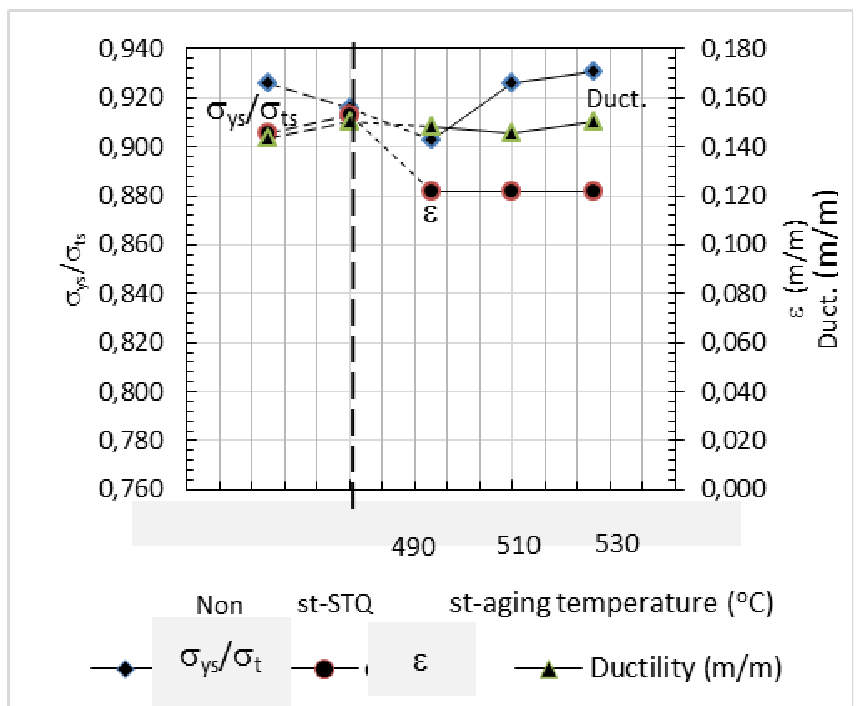

Fig. 4 Change in yield ratio, elongation and ductility of Ti-6Al-4V alloy with short-time solution treatment and subsequent short-time aging for $40 \mathrm{~s}$.

\section{B. Short-time Solution Treatment And Subsquent Short-time Aging for $50 \mathrm{~s}$}

Results of tensile test conducted to alloys which is heat treated by Solution treatment and subsquent aging at various temperature in vacuum furnace, they are 490, 510 dan 530 ${ }^{\circ} \mathrm{C}$ for $50 \mathrm{~s}$ is shown in Table III. 
TABLE III

Change In Mechanical Properties of Ti-6AL-4V with SHORT-Time SOLUTION TREATMENT AND SubSEQUENT SHORT-Time AgING For $50 \mathrm{~S}$

\begin{tabular}{|c|l|c|c|c|c|c|c|c|}
\hline No. & $\begin{array}{l}\text { Type } \\
\text { Treat- } \\
\text { ment }\end{array}$ & $\sigma_{\text {ys }}$ & $\sigma_{\text {ts }}$ & $\varepsilon$ & $\phi$ & $\frac{\sigma_{y s}}{\sigma_{\text {ts }}}$ & $\mathrm{E}$ & Duc. \\
\hline 1 & Non & 1005 & 1086 & 0,145 & 0,34 & 0,93 & 100 & 0,14 \\
\hline 2 & STQ & 1087 & 1187 & 0,153 & 0,47 & 0,92 & 133 & 0,15 \\
\hline 3 & $490^{\circ} \mathrm{C}$ & 1253 & 1363 & 0,127 & 0,37 & 0,92 & 93 & 0,14 \\
\hline 4 & $510^{\circ} \mathrm{C}$ & 1096 & 1203 & 0,127 & 0,34 & 0,91 & 99 & 0,15 \\
\hline 5 & $530^{\circ} \mathrm{C}$ & 1044 & 1183 & 0,113 & 0,33 & 0,97 & 81 & 0,14 \\
\hline
\end{tabular}

By subsquent short-time aging treatment, both yield and tensile strength increased higher than those only sohor-time solution treatment. The highest yield and ultimate tensile strength value in this study are in the heat treated alloys by subsquent Short-time aging at temperature, $\mathrm{T}=490{ }^{\circ} \mathrm{C}$ (783 $\mathrm{K})$. They are 19,8 and $20,3 \%$, respectively. The yield strength increased from 1005 to $1253 \mathrm{MPa}$ and ultimate tensile strength increased from 1086 menjadi $1363 \mathrm{MPa}$. Whereas, the lowest yield and ultimate tensile strength are on heat treated alloys by subsquent Short-time aging at temperature $\mathrm{T}=510{ }^{\circ} \mathrm{C}(783 \mathrm{~K})$. The yield and ultimate tensile strength increased only from 1005 to $1044 \mathrm{MPa}$ and $1086 \mathrm{MPa}$ to $1183 \mathrm{MPa}$, respectively (Figure 5).

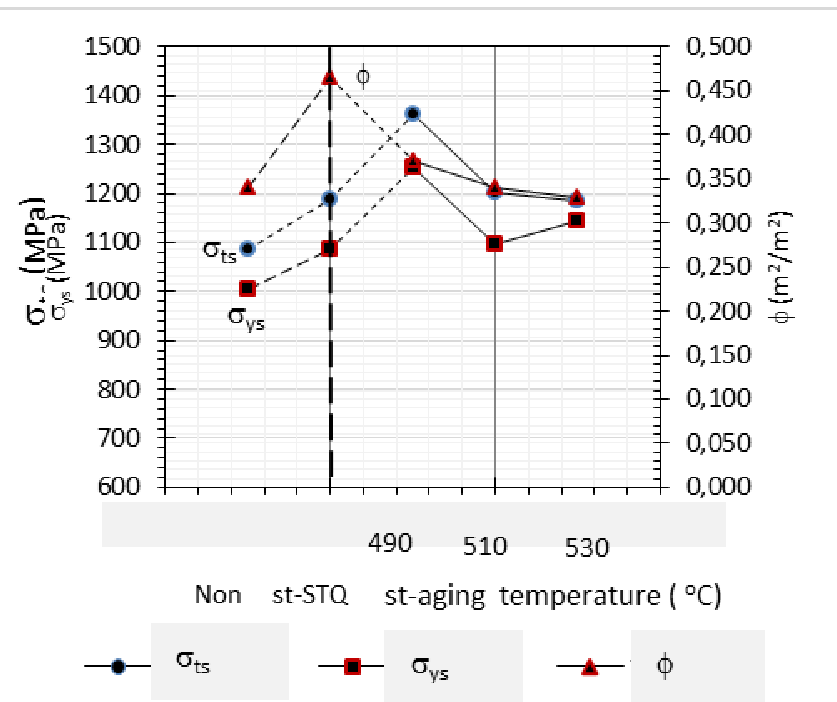

Fig. 5 Change in mechanical properties of Ti-6Al-4V with short-time solution treatment and subsequent short-time aging for $50 \mathrm{~s}$.

Also, on the heat treated alloy by subsquent short-time aging at temperature $\mathrm{T}=490{ }^{\circ} \mathrm{C}(783 \mathrm{~K})$, reduction of area determined in this study is noticeably higher, by as much as $8,1 \%$, than the value obtained in the untreated alloy. It was increased from 34 to $37 \%$. Except at the aging temperature $510{ }^{\circ} \mathrm{C}$, the reduction of area not changed, same as untreated alloy. Whereas, at the aging temperature $530{ }^{\circ} \mathrm{C}$ in this study decreased to $33 \%$ (as shown on Figure 6 or explained in Table III) .

Figure 6 shows the change in tensile properties of alloy due to subsquent short-time aging treatment. Elongation determined in this study is noticeably lower, by as much as 13 to $27 \%$, than the value obtained in the untreated alloy. It was decreased from 15 to $13 \%$ in the subsequent aging temperature of $490,510{ }^{\circ} \mathrm{C}$ and 15 to $11 \%$ at $530{ }^{\circ} \mathrm{C}$.
Also, ductility of subsquent Short-time aging alloy determined in this study is noticeably higher, by as much as $6,6 \%$, than the value obtained in the untreated alloy. It was increased from 14 to $15 \%$. Also, the yield ratio determined in this study is higher, by as much as $4,1 \%$, than the value obtained in the untreated alloy. It was increased from 0,93 to 0,97 only at temperature $530{ }^{\circ} \mathrm{C}(803 \mathrm{~K})$ on this study.

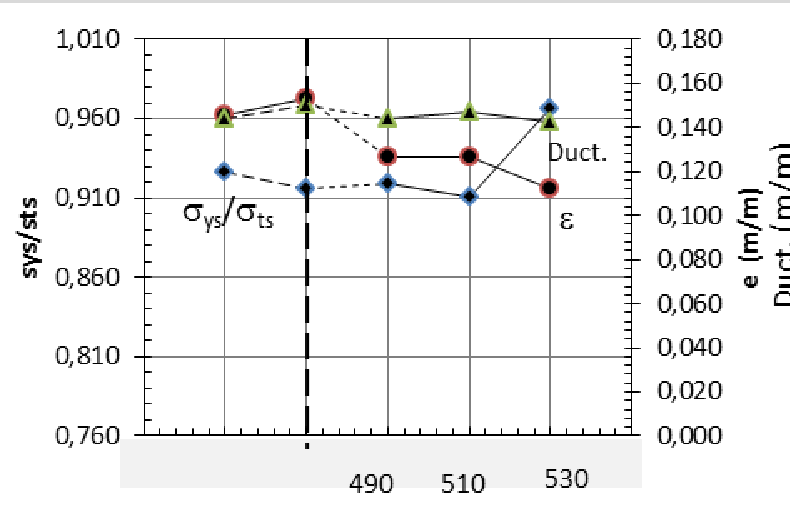

Non st-STQ st-aging temperature $\left({ }^{\circ} \mathrm{C}\right)$

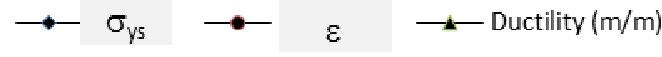

Fig. 6 Change in yield ratio, elongation and ductility of Ti-6Al-4V alloy with short-time solution treatment and subsequent short-time aging for $50 \mathrm{~s}$.

\section{Short-time Solution Treatment And Subsquent Short-time} Aging for $60 \mathrm{~s}$

Results of tensile test conducted to alloys which is heat treated by Short-time solution and subsquent short-time aging at various temperature in vacuum furnace, they are 490,510 dan $530{ }^{\circ} \mathrm{C}$ for $60 \mathrm{~s}$ is shown in Table IV.

TABLE IV

Change In Mechanical Properties OF Ti-6AL-4V With SHORT-Time SOlution Treatment AND SubSEQUENT SHORT-Time AgING For $60 \mathrm{~s}$.

\begin{tabular}{|c|l|c|c|c|c|c|c|c|}
\hline No. & $\begin{array}{c}\text { Type } \\
\text { Treat- } \\
\text { ment }\end{array}$ & $\sigma_{\mathrm{ys}}$ & $\sigma_{\mathrm{ts}}$ & $\varepsilon$ & $\phi$ & $\frac{\sigma_{y s}}{\sigma_{t s}}$ & $\mathrm{E}$ & Duc. \\
\hline 1 & Non & 1005 & 1086 & 0,145 & 0,34 & 0,93 & 100 & 0,14 \\
\hline 2 & STQ & 1087 & 1187 & 0,153 & 0,47 & 0,92 & 133 & 0,15 \\
\hline 3 & $490^{\circ} \mathrm{C}$ & 1142 & 1205 & 0,127 & 0,36 & 0,95 & 98 & 0,14 \\
\hline 4 & $510^{\circ} \mathrm{C}$ & 1013 & 1084 & 0,134 & 0,35 & 0,93 & 111 & 0,14 \\
\hline 5 & $530^{\circ} \mathrm{C}$ & 1064 & 1125 & 0,117 & 0,35 & 0,95 & 108 & 0,14 \\
\hline
\end{tabular}

By subsquent short-time aging treatment, both yield and tensile strength also increased higher than those only Shorttime solution treatment in this study. The highest increasing yield and ultimate tensile strength values in this study are in the heat treated alloys by subsquent Aging at temperature, $\mathrm{T}$ $=490{ }^{\circ} \mathrm{C}(783 \mathrm{~K})$. They are 12 and $10 \%$, respectively. The yield strength increased from 1005 to $1142 \mathrm{MPa}$ and ultimate tensile strength increased from 1086 menjadi 1205 $\mathrm{MPa}$. Whereas, the lowest yield and ultimate tensile strength are on heat treated alloys by subsquent Aging at temperature $\mathrm{T}=510{ }^{\circ} \mathrm{C}(783 \mathrm{~K})$. The yield and ultimate tensile strength increased only from 1005 to $1013 \mathrm{MPa}$ and $1086 \mathrm{MPa}$ to $1094 \mathrm{MPa}$, respectively (Figure 7).

Also, on the heat treated alloy by subsquent short-time aging at temperature $\mathrm{T}=490{ }^{\circ} \mathrm{C}(763 \mathrm{~K})$, reduction of area 
determined in this study is higher, by as much as $5,5 \%$, than the value obtained in the untreated alloy. It was increased from 34 to $36 \%$. Except at the aging temperature $510{ }^{\circ} \mathrm{C}$ and $530{ }^{\circ} \mathrm{C}$ in this study increased from 34 to $35 \%$ only (as shown on Figure 7 or as explained in Table IV).

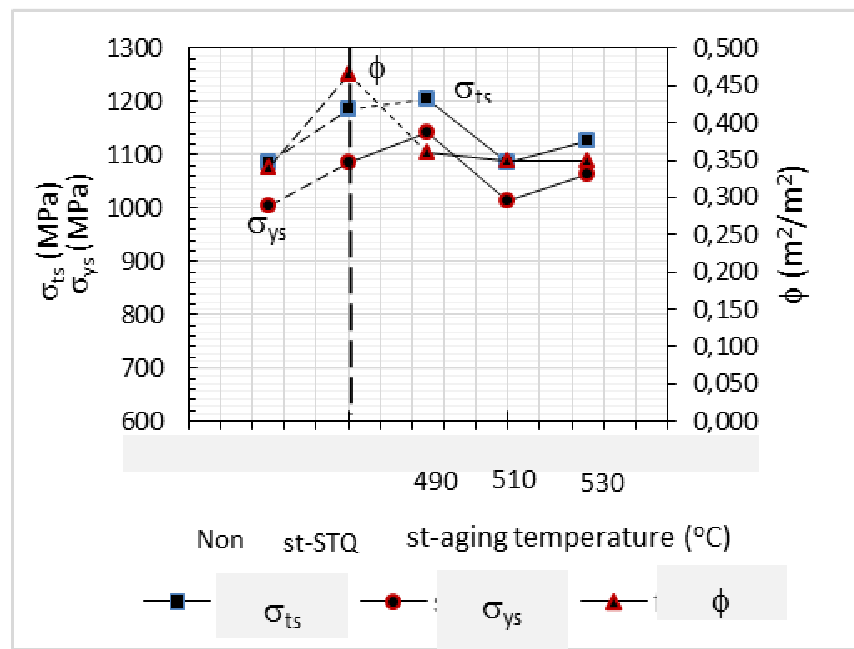

Fig. 7 Change in mechanical properties of Ti-6Al-4V with short-time solution treatment and subsequent short-time aging for $60 \mathrm{~s}$.

Also, the yield ratio determined in this study is higher, by as much as 11 to $21 \%$, than the value obtained in the untreated alloy. It was increased from 0,93 to 0,94 at aging temperature 490 and $530{ }^{\circ} \mathrm{C}(763$ to $803 \mathrm{~K})$ and not changed in aging temperature $510{ }^{\circ} \mathrm{C}$.

Figure 8 shows the change in tensile properties of alloy due to subsquent short-time aging treatment. Elongation determined in this study is noticeably lower, by as much as 13 to $20 \%$, than the value obtained in the untreated alloy. It was decreased from 15 to $13 \%$ in the subsequent aging temperature of $490,510{ }^{\circ} \mathrm{C}$ and 15 to $12 \%$ at $530{ }^{\circ} \mathrm{C}$. Then, the ductility of subsquent short-time aging alloy determined in this study is not changed than the value obtained in the untreated alloy. It is as much as $15 \%$.

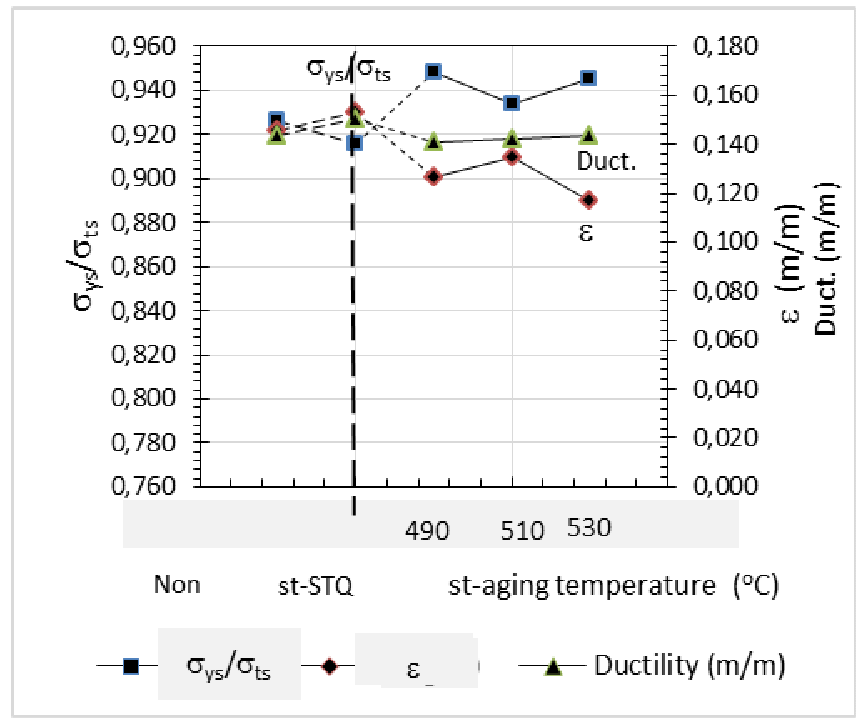

Fig. 8 Change in yield ratio, elongation and ductility of Ti-6Al-4V alloy with short-time solution tretment and subsequent short-time aging for $60 \mathrm{~s}$.
Based on results of study known that static strength of solution treated materials in the $(\alpha+\beta)$ phase field were increased. The static strength increased higher at Short-time subsquent aging treatment materials. The highest increasing yield and ultimate tensile strength values in this study are in the heat treated alloys by subsquent aging at temperature $530{ }^{\circ} \mathrm{C}(803 \mathrm{~K})$. They are 21,6 and $21,1 \%$, respectively.

It is thought that the above remarkable strengthening is mainly due to the refinement of prior $\beta$ phase resulting from the formation of $\alpha^{\prime}$ phase and the precipitation of fine $\alpha$ phase through the short-time solution treatment and subsquent short-time aging [7],[8].

\section{CONCLUSIONS}

Based on results of study known that the most optimum changing in mechanical properties in the study were at Ti$6 \mathrm{Al}-4 \mathrm{~V}$ alloy conducted heat treatment consisting of shorttime solution treatment at $930{ }^{\circ} \mathrm{C}(1203 \mathrm{~K})$ for $60 \mathrm{~s}$ and subsquent aging at $930{ }^{\circ} \mathrm{C}(803 \mathrm{~K})$ for $40 \mathrm{~s}$. With this heat treatment, the yield strength and tensile strength were each increased by about $21,6 \%$ and $21,1 \%$. Then, the reduction of area and elastic modulus were each slightly increased, by about $8 \%$ and $12 \%$.

\section{NOMENCLATURE}

E Young modulus

GPA

Duct. ductility

$\mathrm{m} / \mathrm{m}$

\section{Greek letters}

$\sigma \quad$ strength

$\phi \quad$ reduction of area

$\varepsilon \quad$ elongation

$\mathrm{MPa}$

$\mathrm{m}^{2} / \mathrm{m}^{2}$

$\mathrm{m} / \mathrm{m}$

\section{Subscripts}

ys yield strength

ts tensile strength

Greek letters with subscripts

$\sigma_{\mathrm{ys}} / \sigma_{\mathrm{ts}}$ yield ratio

\section{ACKNOWLEDGMENT}

Firstly, I would like to express my sincere gratitude to my advisor Prof. Dr. Eng. Gunawarman and Dr. Eng. Jon Affi for the continuous support of my Master of Engineering study and related research, for his patience, motivation, and immense knowledge. His guidance helped me in all the time of research and writing of this thesis. I could not have imagined having a better advisor and mentor for my Master of Engineering study.

Besides my advisor, I would like to thank the rest of my thesis committee: Prof. Dr. Eng. Gunawarman, Dr. Eng. Jon Affi, Dr. Is Primananda, and Dr. Ing. Henderi Dahlan, for their insightful comments and encouragement, but also for the hard question which incented me to widen my research from various perspectives. 


\section{REFERENCES}

[1] Abdel-Hady Gepreel, Mohamed, Mitsuo Niinomi, Biocompatibility of Ti-Alloys for Long-Term Implantation, Journal of the Mechanical Behavior of Biomedical Materials. (2013).

[2] Özcan, Mutlu and Christoph Hämmerle, Titanium as a Reconstruction and Implant Material in Dentistry: Advantages and Pitfalls, Materials. 5, 1528-1545. (2012).

[3] Niinomi, Mitsuo. Biologically and Mechanically Biocompatible Titanium Alloys, Materials Transactions, Vol. 49, No. 10 (2008) pp. 2170 to 2178, Special Issue on Advanced Light Metals and Processing in Asia, The Japan Institute of Light Metals. (2008)

[4] Navarro, M. A. Michiardi, O. Castano and J. A. Planell, Review : Biomaterials in orthopaedics. J. R. Soc. Interface (2008) 5, 11371158. doi:10.1098/rsif.2008.0151. (2008)

[5] Song, Yan, Rui Yang and Zheng-Xiao Guo, First Principles Estimation of Bulk Modulus and Theoretical Strength of Titanium Alloys, Materials Transactions, Vol. 43, No. 12, pp. 3028 to 3031, Special Issue on Biomaterials and Bioengineering The Japan Institute of Metals. (2002).

[6] Niinomi, Mitsuo, Recent Research and Development in Titanium Alloys for Biomedical Applications and Healthcare Goods, Science and Technology of Advanced Materials 4, 445-454. (2003).
[7] Morita, T, K. Hatsuoka, T. Iizuka and K. Kawakami, Strengthening of Ti-6Al-4V Alloy by Short-time Duplex Heat Treatment, Materials Transaction, Vol. 46, No. 7, pp. 1681-1686. (2005).

[8] Tanaka, S., T. Morita, K. Shinoda, Effects of Short-Time Duplex Heat Treatment on Microstructure and Fatigue Strength of Ti-6Al-4V Alloy, 13th International Conference on Fracture June 16-21, Beijing, China (2013).

[9] Hermawan, Hendra, Dadan Ramdan and Joy R. P. Djuansjah, Metals for Biomedical Applications, Biomedical Engineering - From Theory to Applications, Prof. Reza Fazel (Ed.), ISBN: 978-953-307-637-9, InTech. (2011).

[10] Lutjering, G. and J. C. Williams: Titanium, (Springer-Verlag Berlin Heidelberg New York. (2003)

[11] Donachie, Matthew J, Titanium: A Technical Guide. ISBN-13: 9780871706867. Edition: $2^{\text {nd }}$. (2000)

[12] ASM Handbook, Fundamentals of Medical Implant Materials: Materials for Medical Devices, Volume 23, ASM International, Materials Park, Ohio, USA. (2012).

[13] ASTM E8/E8M-11, Standard Test Methods for Tension Testing of Metallic Materials, ASTM International, 100 Barr Harbour Dr., PO Box C700 West Conshohocken, PA. 19428-2959, United States. 